\title{
ANALISIS SELF EFFICACY DAN HASIL BELAJAR MATEMATIKA SISWA DI MAN 2 BATUSANGKAR BERDASARKAN GENDER
}

\author{
Wahidah Fitriani ${ }^{1}$ \\ wahidahfitriani1679@gmail.com
}

\begin{abstract}
Abstrak: Self efficacy dan hasil belajar matematika antara siswa dan siswi cenderung berbeda. Siswa selama ini dianggap memiliki self efficacy dan hasil belajar matematika yang lebih tinggi dibandingkan dengan siswi. Penulis ingin menguji secara empirik dan mencari hubungan antara self efficacy dengan hasil belajar matematika siswa maupun siswi, sekaligus perbedaan self efficacy antara keduanya. Data dikumpulkan melalui angket self efficacy dan hasil belajar matematika yang dilihat di rapor, lalu dianalisis dengan metode korelasi. Hasil penelitian menunjukkan tidak terdapat hubungan antara self efficacy dengan hasil pembelajaran matematika siswa maupun siswi, dan tidak terdapat perbedaan yang signifikan antara self efficacy siswa dan siswi.
\end{abstract}

Kata kunci: Self Efficacy, Hasil belajar matematika

\section{PENDAHULUAN}

Dalam kehidupan sehari-hari, manusia tak akan pernah lepas dari perhitungan dan angka-angka. Begitu pula dalam pendidikan, salah satu cabang pendidikan yang berperan penting dalam kehidupan manusia adalah matematika. Matematika hampir digunakan dalam setiap kegiatan kehidupan sehari-hari, dalam proses jual beli, menghitung jarak dan waktu, hingga untuk membuat gedung pencakar langit, manusia membutuhkan perhitungan atau matematika. Maka tak dapat dipungkiri jika peradaban manusia dapat berubah dengan pesat karena ditunjang oleh kontribusi matematika yang berkembang mengikuti perubahan zaman.

\footnotetext{
${ }^{1}$ Penulis merupakan Kepala Pusat Studi Gender dan Anak IAIN Batusangkar
} 
Proses pembelajaran matematika meliputi tiga unsur utama, yaitu tujuan pengajaran (instructional objectives), pengalaman belajar (learning experience), dan hasil belajar (learning outcome). Salah satu faktor internal yang mempengaruhi hasil belajar adalah psikologi siswa, khususnya self efficacy (Ghufron dan Risnawita, 2011: 6). Self efficacy pertama kali dikembangkan oleh Albert Bandura. Bandura (1997) mendefinisikan self efficacy dengan "keyakinan individu mengenai kemampuan dirinya dalam melakukan tugas atau tindakan yang dilakukan dalam mencapai hasil tertentu. Selain keyakinan diri, self efficacy juga memiliki makna penilaian diri, apakah dapat melakukan tindakan baik atau buruk, tepat atau salah, bisa atau tidak bisa mengerjakan sesuai dengan yang dipersyaratkan. Bandura juga menggambarkan self efficacy sebagai rasa keberhargaan diri atau kelayakan diri, perasaan tentang kecakapan diri, efisiensi, dan kompetensi dalam menangani masalah.

Berdasarkan pernyataan Bandura tersebut dapat dipahami bahwa self efficacy adalah hasil dari proses koginitif individu berupa keyakinan individu terhadap kemampuan individu tersebut dalam belajar sehingga mampu mendapatkan hasil belajar yang diinginkan. Individu yang bisa mencapai hasil, tujuan, dan bisa mengatasi rintangan biasanya memiliki self efficacy yang tinggi. Tampaknya sangat jelas bahwa self efficacy yang tinggi akan berkontribusi secara positif hampir dalam semua aspek kehidupan. Orang yang memiliki self efficacy rendah akan merasa tak berdaya, bahkan putus asa dalam menghadapi keadaan dan berpikir kalau mereka hanya punya kemungkinan kecil untuk dapat mempengaruhi situasi yang mereka hadapi. Vogt., dkk (2007) menemukan bahwa laki laki memiliki self efficacy yang lebih tinggi daripada perempuan.

Terdapat beberapa bidang di mana perempuan lebih unggul daripada laki-laki, atau pun sebaliknya, laki-laki lebih unggul dibandingkan perempuan. Rata-rata, perempuan memiliki performa lebih baik dari pada laki-laki di bidang kemampuan bahasa, memori verbal, kecepatan persepsi, dan keterampilan motorik halus. Sedangkan laki-laki memiliki performa lebih baik daripada perempuan di bidang 
matematika, sains, dan ilmu sosial (Halpern, 2004: Stumpf \& Stanley, 1998). Kebanyakan perbedaan gendernya cukup kecil, namun rata-rata laki-laki cenderung mendapat skor lebih tinggi pada tes spasial dan penalaran mekanik, estimasi terhadap kecepatan perpindahan benda, dan ruang tiga dimensi. Perbedaaan gender ini telah ditemukan pada kebanyakan budaya di seluruh dunia (Halpern, 2004).

Selanjutnya, Bassey, dkk (2008) melakukan sebuah studi mengenai "Perbedaan Gender dan Hasil Belajar Matematika pada Siswa SMA Pedesaan di Cross River State, Nigeria". Hasil penelitian tersebut menunjukkan bahwa dalam mata pelajaran Matematika, laki-laki lebih unggul dibandingkan dengan perempuan. Perempuan dalam pembelajaran yang dilakukan di kelas, identik dengan keterampilan "pekerjaan ibu rumah tangga". Mereka dituntut bersikap tenang, bersifat menghargai, penuh perhatian, dapat dipercaya, serta mau bekerja sama. Untuk laki-laki harapan lebih didasarkan pada kriteria kemampuan akademik seperti pengetahuan, kecakapan intelektual, dan kebiasaan kerja.

Berdasarkan temuan Halpern (2004), Vogt, dkk (2007) dan Bassey, dkk (2008) tersebut, maka peneliti tertarik untuk meneliti lebih jauh dan membuktikan di lapangan mengenai self efficacy dan hasil belajar matematika siswa di MAN 2 Batusangkar berdasarkan gender.

\section{PEMBAHASAN}

\section{Self Efficacy dan Gender}

Dalam kehidupan sehari hari dapat diamati bahwasannya self efficacy sangat dibutuhkan atau sangat berperan penting dalam pendidikan ataupun dalam komunikasi. Jadi untuk mengembangkan pendidikan dan untuk memajukan generasi, guru juga harus melihat dan memperhatikan self efficacy siswa yang harus dikembangkan secara bersamaan dengan kegiatan belajar mengajar. Karena semakin meningkatnya self efficacy siswa maka akan lebih bagus dan lebik baik cara pandangnya dan lebih giat dalam melakukan berbagi hal. 
Self efficacy adalah kemampuan dalam menghadapi berbagai macam peristiwa dalam kehidupan, kekuatan untuk percaya bahwa diri sendiri bisa, kemampuan berpikir bahwa diri sendiri dapat meraih apa yang diinginkan merupakan salah satu factor yang mempengaruhi kesuksesan seseorang (Ghufron dan Risnawita, 2010: 76). Selanjutnya Gits dan Mitchell mengatakan bahwa "self efficacy dapat membawa pada perilaku yang berbeda di antara individu dengan kemampuan yang sama, karena self efficacy mempengaruhi pilihan, tujuan, pengentasan masalah dan kegigihan dalam berusaha" (Ghufron dan Risnawita, 2010: 75). Selanjutnya Ormrod (2008) menjelaskan bahwa self efficacy secara umum merupakan "penilaian seseorang tentang kemampuannya sendiri untuk menjalankan perilaku tertentu atau mencapai tujuan tertentu. Sedangkan menurut Santrock (2011: 216) self efficacy merupakan keyakinan bahwa seseorang menguasai situasi dan memberikan hasil positif.

Dengan demikian dapat disimpulkan bahwa self efficacy merupakan kemampuan seseorang dalam melakukan tugas dan tindakan untuk menggapai apa yang menjadi tujuannya. Self efficacy yang dimaksud bukanlah yang berkaitan dengan kepribadian, ciri fisik ataupun karakteristik seseorang, bukan juga tentang kecakapan yang dimiliki, tetapi yang berkaitan dengan bagaimana seseorang mampu meyakini dirinya untuk bisa melakukan sesuatu untuk mencapai tujuannya atau memotivasi diri agar berpikir jika ia bisa. Contoh dari self efficacy yang dimaksud yaitu: sebagai seorang siswa, dengan kemampuan dan keyakinan yang dimiliki, dia mampu memotivasi dirinya sendiri untuk belajar sehingga bisa memperoleh hasil belajar yang memuaskan. Dengan kata lain, dia berharap akan memiliki self efficacy yang tinggi dalam rangka meningkatkan hasil belajarnya. Hal tersebut merupakan bentuk dari self efficacy yang tidak hanya berkaitan pada sejumlah keterampilan yang dimiliki seseorang, melainkan menyangkut keyakinan untuk melakukan sesuatu.

Self efficacy dapat dibedakan dalam dua kategori, yaitu self efficacy tinggi dan self efficacy rendah. Siswa yang memiliki self efficacy tinggi cenderung mendapatkan nilai yang lebih baik, mempertimbangkan lebih banyak kemungkinan karir, memiliki 
kesuksesan pekerjaan yang lebih besar, menetapkan tujuan pribadi yang lebih tinggi, dan memiliki kesehatan fisik dan mental yang lebih baik daripada siswa yang memiliki self efficacy rendah. Sedangkan siswa yang memiliki self efficacy rendah cenderung mendapatkan nilai yang rendah, mudah putus asa, dan cendrung merasa tak berdaya, jika menemui masalah. Mereka cenderung akan menyerah ketika upaya awal mereka untuk mendapatkan solusi gagal, mereka mudah khawatir, cemas, merasa takut, depresi dan stres (Bandura: 1997).

Berdasarkan pendapat tersebut diketahui bahwa orang-orang yang memiliki self efficacy yang rendah tidak akan yakin kalau ia bisa melakukan sesuatu dengan baik karena mereka cenderung akan mudah menyerah dan tidak akan mencegah berbagai rintangan atau hambatan yang mungkin muncul. Selanjutnya orang yang memiliki self efficacy rendah juga tidak akan bisa termotivasi dalam melakukan hal apapun, bahkan mereka tidak akan bisa membantu dirinya termotivasi dalam belajar. Hal ini berbeda dengan siswa yang memiliki self efficacy yang tinggi. Siswa yang memiliki self efficacy tinggi akan bisa membantu dirinya termotivasi dalam belajar sehingga hasilhasil belajarnya juga akan memuaskan.

Bandura (1997) menyatakan bahwa self efficacy memiliki fungsi yang pertama dalam pilihan perilaku dimana individu akan menetapkan tindakan apa yang akan ia lakukan dalam menghadapi suatu tugas untuk mencapai tujuan yang diinginkannya. Kedua, ketekunan, semakin kuat dirasakan self efficacy, semakin kuat dan gigih mereka dalam berusaha. Ketiga, pola fikir dan reaksi emosional, orang yang memiliki self efficacy yang kuat akan memiliki keinginan untuk berhasil yang kuat pula, ia akan mengerahkan perhatian dan usahanya dengan tuntutan situasi bagi upaya yang lebih besar. Keempat, produktivitas, dimana orang yang menganggap dirinya mampu akan melakukan hal-hal yang membuatnya berhasil di masa depan, bukan sekedar meramalkannya.

Self efficacy juga berkontribusi terhadap keadaan emosi seseorang. Salah satu akibat yang ditimbulkan apabila self efficacy rendah adalah suasana hati atau mood 
yang negatif. Individu dengan self efficacy rendah cenderung mempunyai perasaan depresi dan perasaan tidak berdaya yang lebih besar dibandingkan dengan individu dengan self efficacy yang tinggi. Bagi siswa yang berkemampuan lebih, mereka biasanya lebih kreatif. Siswa dengan kemampuan yang sedang dan memiliki keyakinan diri yang kurang dan rata-rata belajar sesuai dengan mood, tidak memaksakan diri dan bersikap santai. Tetapi siswa yang dengan kemampuan dan keyakinan diri yang lebih mampu mengatasi kejenuhan dengan sekejap dan dengan cara yang relevan. Jadi, self efficacy siswa memiliki pengaruh yang signifikan terhadap proses dan hasil belajar.

Dengan demikian, self efficacy yang baik dapat meningkatkan prestasi dan kesejahteraan siswa. Self efficacy mempengaruhi orang membuat pilihan dan tindakan yang mereka lakukan. Individu cenderung untuk memilih tugas-tugas dan kegiatan dimana mereka merasa kompeten dan percaya diri. Self efficacy juga membantu menentukan berapa lama mereka akan bertahan ketika berhadapan dengan rintangan, dan bagaimana mereka akan tangguh dalam menghadapi situasi yang merugikan. Semakin tinggi self efficacy, semakin besar usaha, ketekunan, dan ketahanan. Orang dengan self efficacy yang tinggi menjadikan tugas yang sulit sebagai tantangan untuk dikuasai bukan sebagai ancaman yang harus dihindari. Selain itu, mereka lebih cepat bangkit setelah mengalami kegagalan atau kemunduran, dan kegagalan hanya dijadikan alasan dari masih kurangnya pengetahuan. Bagi siswa yang memiliki perasaan self efficacy yang tinggi, maka ia akan selalu menciptakan hal-hal baru untuk bisa membantu dirinya agar bisa termotivasi dalam belajar. Siswa yang memiliki perasaan self efficacy yang tinggi biasanya lebih memilih pekerjaan yang menantang dan mau menghadapi berbagai macam rintangan yang ada.

Ditinjau dari segi jenis kelamin, laki-laki dan perempuan cenderung memiliki self efficacy yang berbeda. Dalam budaya tertentu, individu dengan peran gender lakilaki memiliki efikasi diri lebih tinggi dibanding mereka yang dengan peran gender perempuan. Laki-laki memiliki perkiraan yang lebih tinggi (overestimate) mengenai seberapa baik mereka mampu mengerjakan sebuah tugas baru, sementara perempuan memiliki perkiraan yang lebih rendah (underestimate) mengenai performanya. Serupa 
dengan hal tersebut, laki-laki memiliki harapan yang lebih tinggi terhadap kesuksesan pekerjaan dan menempatkan lebih banyak penekanan pada gaji daripada perempuan (Baron\&Byrne dalam Hadaning (2014).

Selanjutnya, Santrock (2008: 538) menyatakan bahwa self efficacy yang berkaitan dengan kompetensi belajar antara murid laki-laki dan murid perempuan berbeda-beda menurut konteks hasil belajar yang dicapainya. Misalnya, murid laki-laki lebih memiliki keyakinan kompetensi yang tinggi untuk pelajaran matematika dan olahraga, sedangkan murid perempuan memiliki keyakinan kompetensi lebih tinggi untuk mata pelajaran bahasa Inggris, membaca, dan aktifitas sosial.

Perbedaan gender dalam pelajaran matematika dapat pula terbentuk karena situasi belajar mengajar. Ketika murid perempuan dengan kemampuan yang tinggi dalam pelajaran matematika dihadapkan ke dalam situasi belajar kelompok yang beranggotakan jenis kelamin campuran, kemampuan mereka akan lebih buruk dibandingkan dengan situasi belajar dengan kelompok sesama perempuan. Sedangkan perfoma lelaki tidak terpengaruh. Hal ini sesuai dengan pernyataan Baron \&Byrne (dalam Hadaning, 2014) bahwa stereotip gender tentang kemampuan, membuat situasi dimana anggota kelompok dengan gender berbeda menjadi lebih mengancam bagi perempuan.

\section{Hasil Belajar Matematika dan Gender}

Pengertian hasil belajar menunjukkan pada suatu perolehan akibat dilakukannya suatu aktivitas atau proses yang mengakibatkan berubahnya input secara fungsional (Purwanto, 2009: 44). Menurut Sudjana (2004) hasil belajar merupakan "kemampuan-kemampuan yang dimiliki oleh siswa setelah menerima pengalaman belajar. Sedangkan Abdurrahman (2003: 37) menjelaskan bahwa hasil belajar merupakan kemampuan yang diperoleh anak setelah mengikuti kegiatan belajar mengajar. Dari beberapa ahli tersebut dapat disimpulkan bahwa hasil belajar matematika merupakan kemampuan yang diterima oleh siswa dalam proses belajar matematika sehingga kemampuan tersebut bisa digunakan dalam bentuk perbuatan. 
Siswa akan menjadi lebih baik jika telah mendapatkan pemahaman yang lebih baik lagi.

Hasil belajar sering sekali digunakan sebagai ukuran untuk mengetahui seberapa jauh seseorang menguasai bahan yang sudah diajarkan. Untuk mengaktualisasikan hasil belajar tersebut diperlukan serangkaian pengukuran menggunakan alat evaluasi yang baik dan memenuhi syarat. Alat untuk mengukur hasil belajar seseorang biasanya dengan mengadakan ujian-ujian, baik ujian-ujian kecil seperti tanya jawab sebelum memulai pelajaran yang baru maupun ulangan harian, ujian tengah semester dan ujian semester.

Hasil belajar atau perubahan perilaku yang menimbulkan kemampuan dapat berupa hasil utama proses pembelajaran, maupun hasil sampingan. Hasil utama pengajaran adalah kemampuan hasil belajar yang memang direncanakan untuk diwujudkan dalam kurikulum dan tujuan pembelajaran. Menurut Sudjana (2004: 49) tujuan pendidikan dan pengajaran dapat dikategorikan menjadi tiga bidang yakni bidang kognitif (penguasaan intelektual), bidang afektif (berhubungan dengan sikap dan nilai) dan bidang psikomotor (kemampuan atau keterampilan bertindak atau berperilaku). Ketiga hasil belajar memiliki interdepensi yang merupakan kesatuan yang tidak bisa dipisahkan karena ketiga jenis hasil belajar ini saling berkaitan dan menjadi pedoman bagi guru pembimbing menentukan tinggi rendahnya hasil belajar matematika siswa.

Ada beberapa pelabelan negatif (stereotipe) gender dalam hal kemampuan matematika, yang merugikan salah satu jenis kelamin, khususnya perempuan. Stereotipe pertama, perempuan tidak memiliki kemampuan STEM (Science, Technology, Engineering \& Math) yang baik, sehingga hanya sedikit perempuan yang dianggap mampu bertahan di fakultas yang didominasi oleh laki-laki seperti Teknik dan MIPA. Stereotipe ini menimbulkan kecemasan bagi individu, khususnya 
perempuan dalam mengerjakan tugas yang berkaitan dengan STEM, dan membuatnya cenderung menghindari tugas dan karier yang berhubungan dengan matematika.

Selanjutnya Maloney, Waechter, Risko, dan Fugelsang (dalam Debineva, 2016) menunjukkan bahwa terdapat perbedaan kemampuan spasial antar perempuan dan laki-laki. Sementara Estes dan Felker (dalam Debineva, 2016) ) menemukan bahwa perbedaan kemampuan spasial antara laki-laki dan perempuan dimediasikan oleh kepercayaan diri. Buku nonfiksi popular yang berjudul Why Men Don't Listen dan Why Women Can't Read Road Maps (Pease \& Pease, 1999), yang telah dicetak ulang sebanyak berkali-kali, menggambarkan pasangan Ray dan Ruth yang berbeda pendapat mengenai lokasi pertemuan, di mana Ruth tidak bisa membaca lokasi tujuan mereka tanpa memutar-mutar peta, sementara Ray berada di belakang kemudi. Dalam buku tersebut digambarkan perbedaan fungsi otak, di mana laki-laki lebih dominan dalam mempersepsi ruang. Sementara perempuan tidak memiliki kemampuan mempersepsi ruang sebaik laki-laki. Stereotipe ini telah diterima secara luas. Implikasinya, misalnya, terdapat pembatasan akses perempuan pada pekerjaan membutuhkan navigasi, seperti supir, pilot, navigator, dan nahkoda, yang selalu didominasi bahkan dipersyaratkan dengan jenis kelamin tertentu, yaitu laki-laki (Debineva, 2016)

Beberapa bidang dimana dapat ditemukan perbedaan gender yang reliabel berkaitan dengan kemampuan psikologis, khususnya dalam area-area yang menyangkut kemampuan berpikir, persepsi dan memori. Pada umumnya, laki-laki (sejak kecil hingga dewasa) memperlihatkan kemampuan spasial yang lebih baik, lakilaki lebih mahir dalam mengerjakan tugas-tugas dan tes-tes yang mengukur kemampuan spasial, mengetahui lebih banyak mengenai geografi dan politik serta sejak SMA memiliki kemampuan matematika yang lebih baik, meskipun perbedaannya kecil.

Selama masa Sekolah Dasar ada bukti kuat bahwa perempuan lebih unggul ketimbang laki-laki dalam hal membaca dan menulis. Dalam studi nasional baru-baru ini, perempuan punya prestasi lebih tinggi dibanding laki-laki di grade 4,8 , dan 12 , dan 
selisih ini terus melebar seiring dengan kenaikan murid di sekolah. Selanjutnya, lakilaki lebih besar kemungkinan drop out dari sekolah ketimbang wanita, meskipun perbedaannya kecil. Perempuan (90\%) lebih mungkin menyelesaikan pendidikan sekolah menengah atas ketimbang laki-laki (87\%).Walaupun banyak anak laki-laki yang prestasinya bagus, tetapi 50\% dari jumlah murid yang prestasinya tidak bagus adalah anak laki-laki. Anak perempuan lebih mungkin untuk mempelajari materi akademik, penuh perhatian di kelas, mau belajar lebih tekun, dan berpartisipasi lebih banyak di kelas ketimbang anak laki-laki (Santrock: 2008).

\section{Kaitan Self Efficacy dan Hasil Belajar Matematika.}

Dalam belajar, apabila semua siswa memiliki perasaan self efficacy yang tinggi, maka hasil belajar siswa juga akan lebih memuaskan. Sebab, siswa yang memiliki perasaan self efficacy yang tinggi akan selalu menstimuli motivasinya untuk belajar. Dengan begitu, semakin banyak siswa yang memiliki perasaan self efficacy yang tinggi, maka pendidikan di sekolahpun juga dapat dikatakan berhasil dengan baik. Selanjutnya, Bandura (dalam Pajares \&Schunk, 2016) mengemukakan pendapatnya mengenai Self efficacy yaitu: "Self efficacy beliefs influence task choice, effort, persistence, resilience and achievement compared with students who doubt their learning capabilities, those who feel efficacious for learning or performing task will take part. The notion of perceived control also differs from self efficacy people who believe they can control what they learn and perform are more apt to initiate and sustain behaviors directed toward those ends than the individuals who hold a low sense of control over their capabilities.

Berdasarkan pendapat Bandura tersebut dapat dipahami bahwa siswa yang memiliki self efficacy tinggi lebih mudah berpartisipasi, seperti: bisa memberikan ideide yang cemerlang, aktif, bekerja keras, bertahan lebih lama, menunjukkan minat yang besar dalam belajar, dan lain sebagainya. Siswa denganself efficacy tinggi mampu meningkatkan kinerja dirinya dalam belajar. Begitupun ketika membantu dirinya agar bisa termotivasi dalam belajar, siswa yang memiliki self efficacy tinggi akan selalu 
berusaha sekuat tenaga untuk memotivasi dirinya dan mencegah berbagai hambatan yang mungkin timbul dalam rangka menimbulkan motivasi belajarnya.

Salah satu contoh dari perasaan self efficacy yang tinggi menimbulkan motivasi belajar dan mencegah hambatan yang mungkin muncul yaitu: ketika seorang siswa mengalami kesulitan atau hambatan dalam mengerjakan sebuah tugas matematika, maka siswa yang memiliki perasaan self efficacy diri yang tinggi akan selalu yakin dengan kemampuan yang dimiliki bahwa ia bisa mengerjakan atau memecahkan soal-soal tersebut dengan baik dan berusaha untuk menghilangkan perasaan tidak mampu untuk mengerjakan soal tersebut demi memperoleh hasil yang memuaskan. Siswa ini akan terus berfikir bagaimana caranya memecahkan soal matematika tersebut.

Self efficacy tinggi atau keyakinan yang tinggi sangat penting dimiliki oleh siswa dalam belajar, karena apabila siswa telah termotivasi dalam belajar, maka mereka akan melakukan berbagai cara untuk mewujudkan keyakinannya tersebut. Dengan keyakinan tersebut siswa akan terus berusaha apabila menghadapi kegagalan. Melihat keyakinan siswa yang begitu kuat dalam memotivasi dirinya, maka secara tidak langsung akan timbul motivasi dari dalam diri mereka sehingga termotivasi untuk belajar. Apabila siswa telah termotivasi dalam belajar, maka hasil-hasil belajar siswapun juga tidak akan diragukan lagi.

Berdasarkan pendapat tersebut diketahui bahwa self efficacy merupakan bentuk dari motivasi instrinsik siswa. Jika siswa memiliki keyakinan yang tinggi dalam memotivasi dirinya, maka ia akan melakukan berbagai cara dalam rangka menimbulkan motivasi belajarnya. Sebaliknya apabila siswa memiliki rasa self efficacy yang rendah, maka siswa tersebut tidak akan bisa membantu dirinya termotivasi dalam belajar. Dengan demikian, terlihat pengaruh self efficacy siswa, terhadap motivasi belajarnya sehingga siswapun memperoleh hasil belajar yang memuaskan. 


\section{METODE PENELITIAN}

Jenis penelitian ini adalah penelitian lapangan (field research) dalam bentuk penelitian penelitian deskriptif. Adapun metode yang digunakan adalah gabungan dari metode kuantitatif dan kualitatif. Hasil deskripsi dari metode kuantitatif yang berupa bilangan maupun uraian singkat tentang suatu gejala sosial, masih memerlukan pendalaman. Untuk memenuhi keperluan tersebut, dapat dilengkapi dengan metode kualitatif. Penelitian kualitatif deskriptif tidak dimaksudkan untuk mengkaji hipotesis tertentu, tetapi hanya menggambarkan apa adanya tentang suatu variabel, gejala atau keadaan (Arikunto: 2005). Penelitian ini menggambarkan secara sistematis dan akurat mengenai fakta-fakta, sifat-sifat dan fenomena-fenomena yang diselidiki, yaitu menganalisis hubungan self efficacy dengan hasil belajar siswa berdasarkan gender. Penelitian kualitatif dapat digunakan untuk memperdalam hasil penelitian kuantitatif, antara lain melalui kegiatan wawancara.

Subjek penelitian ini adalah seluruh siswa kelas XI IPA 2 MAN 2 Batusangkar tahun pelajaran 2015/2016 yang berjumlah 34 orang siswa. Pemilihan subjek penelitian dilakukan melalui teknik purposive sampling, yaitu berdasarkan tujuan penelitian berupa keberagaman jenis kelamin siswa. Berdasarkan informasi dari pihak sekolah, kelas tersebut adalah kelas dengan jenis kelamin siswa yang paling seimbang, yang mana terdiri dari 15 orang siswa laki-laki dan 19 orang siswa perempuan. Data kuantitatif yang dimaksud dalam penelitian ini adalah berupa penyajian angket yang diberikan kepada 15 siswa laki-laki dan 15 siswa perempuan kelas XI IPA 2 MAN 2 Batusangkar, yang memuat seluruh indikator-indikator self efficacy yang bertujuan untuk mengetahui tingkat self efficacy siswa secara tertulis. Sementara itu, data kualitatif yang dimaksud dalam penelitian ini adalah hasil wawancara peneliti dengan siswa kelas XI IPA 2 yang mana isi dari wawancara tersebut tidak keluar dari pertanyaan-pertanyaan seputar indikator-indikator self efficacy. Subjek penelitian

untuk sumber data kualitatif adalah beberapa orang siswa laki-laki dan siswa perempuan yang diambil berdasarkan kebutuhan data dari analisis tes hasil belajar 
siswa sebelumnya. Teknik pengumpulan data dalam penelitian ini ada 2 cara, yaitu meminta subjek penelitian untuk mengisi angket dan mewawancara beberapa subjek penelitian untuk mengkonfirmasi keabsahan data pengisian angket dan hasil belajar matematika siswa.

\section{HASIL PENELITIAN}

Setelah dilakukan pengumpulan data, diperoleh informasi bahwa self efficacy siswa laki-laki dan siswa perempuan di Kelas XI IPA 2 MAN 2 Batusangkar rata-rata berada pada kategori sedang dan tinggi. Terdapat 7 orang siswa laki-laki yang memiliki self efficacy yang sedang dan terdapat 7 orang siswi perempuan yang juga memiliki self efficacy sedang. Sedangkan sisanya yaitu, 8 orang siswa laki-laki memiliki self efficacy pada kategori tinggi dan 8 orang siswi perempuan yang memiliki self efficacy pada kategori tinggi pula. Selanjutnya dilihat dari hasil belajar matematika, rata-rata siswa laki-laki dan siswi perempuan memperoleh hasil belajar matematika yang berada di atas Kriteria Ketuntasan Minimal (KKM). Untuk lebih jelasnya melihat skor self efficacy dan hasil belajar siswa MAN 2 Batusangkar, dapat dilihat pada tabel 1 berikut ini:

Tabel 1.

Skor Self efficacy dan hasil belajar matematika siswa

\begin{tabular}{lllllll}
\hline No & Siswa & $\begin{array}{l}\text { Self } \\
\text { Efficacy }\end{array}$ & $\begin{array}{l}\text { Hasil } \\
\text { Belajar } \\
\text { Matematika }\end{array}$ & Siswi & $\begin{array}{l}\text { Self } \\
\text { Efficacy }\end{array}$ & $\begin{array}{l}\text { Hasil } \\
\text { Belajar } \\
\text { Matematika }\end{array}$ \\
\hline 1 & AR & 108 & 81 & AF & 122 & 80 \\
\hline 2 & AG & 111 & 79 & DRP & 126 & 81 \\
\hline 3 & AJP & 89 & 80 & HAL & 118 & 81 \\
\hline 4 & AR & 115 & 80 & IAR & 95 & 81 \\
\hline 5 & AR & 116 & 80 & MG & 94 & 80 \\
\hline 6 & CMW & 105 & 80 & NN & 99 & 80 \\
\hline 7 & FGW & 99 & 80 & NT & 114 & 84 \\
\hline
\end{tabular}




\begin{tabular}{lllllll}
\hline 8 & FJ & 119 & 81 & NE & 134 & 92 \\
\hline 9 & FH & 118 & 81 & NU & 105 & 80 \\
\hline 10 & GA & 110 & 81 & PIS & 118 & 83 \\
\hline 11 & INS & 100 & 81 & RM & 104 & 83 \\
\hline 12 & MR & 115 & 81 & SPD & 119 & 82 \\
\hline 13 & MI & 121 & 89 & SA & 117 & 85 \\
\hline 14 & QR & 131 & 82 & TR & 110 & 80 \\
\hline 15 & RK & 129 & 80 & WS & 136 & 82 \\
\hline
\end{tabular}

Setelah dilakukan penghitungan statistik dengan menggunakan Pearson Product Moment untukmenguji hipotesis penelitian, hasilnya menunjukkan bahwa (1) tidak terdapat hubungan yang signifikan antara self efficacy siswa laki-laki dengan hasil belajar matematika siswa laki-laki di kelasXI IPA 2 MAN 2 Batusangkar karena ritung $=0,307340428<\mathrm{r}_{\text {tabel }}=0,514$. (2) tidak terdapat hubungan yang signifikan antara self efficacy siswi perempuan dengan hasil belajar matematika siswi perempuan di kelas XI IPA2MAN2Batusangkar karena $\mathrm{r}_{\text {hitung }}=0,504675<\mathrm{r}_{\text {tabel }}=0,514$. (3) terdapat hubungan yang signifikan antara self efficacy siswa secara keseluruhan dengan hasil belajar matematika siswa secara keseluruhan di kelas XI IPA 2 MAN 2 Batusangkar karena $r_{\text {hitung }}=0,4304277>r_{\text {tabel }}=0,361$, Artinya jika skor self efficcacy dan hasil belajarsiswa laki-laki dan siswa perempuan di kelas XI IPA 2 MAN 2 Batusangkar digabungkan baru dihitung korelasinya, maka hasilnya menunjukkan adanya hubungan yang signifikan antara self efficacy dengan hasil belajar. (4) tidak terdapat perbedaan yang signifikan antara self efficacy siswa laki-laki dan siswa perempuan karena setelah dihitung melalui student $t$ test hasilnya menunjukkan $t_{\text {hitung }}=0,385<t_{\text {tabel }}=2,048$. Artinya self efficacy siswa laki-laki dan self efficacy siswa perempuan tidak berbeda secara signifikan.

Hasil penelitian ini sangat menarik untuk dicermati, bahwa ternyata untuk wilayah yang berbeda, hasil penelitiannya pun berbeda. Penelitian sebelumnya menemukan bahwa siswa laki-laki lebih unggul di bidang matematika (Maccoby \& 
Jacklin, 1974). Namun, dengan adanya perubahan dan perkembangan zaman, akses perempuan dalam pendidikan dan pembelajaran matematika semakin terbuka, perbedaan antara hasil belajar matematika siswa laki-laki dan siswi perempuan semakin memudar. Bahkan American Psychological Association (yang dikutip oleh Lestari dalam Nafi'an, 2011) mengemukakan bahwa berdasarkan analisis terbaru dari penelitian internasional kemampuan perempuan di seluruh dunia dalam matematika tidak lebih buruk daripada kemampuan laki-laki meskipun laki-laki memiliki kepercayaan diri yang lebih dari perempuan dalam matematika, dan perempuanperempuan dari negara dimana kesamaan gender telah diakui menunjukkan kemampuan yang lebih baik dalam tes matematika. Hal ini diperkuat dari hasil penelitian Ekawati \& Wulandari (2011) menunjukkan tidak terdapat perbedaan yang signifikan antara siswa dan siswi dalam kemampuan geometri.

Penelitian ini sesuai dengan hasil penelitian Zubaidah (2011) yang menunjukkan bahwa hasil penelitian tentang kemampuan berpikir kreatif matematika, kemampuan komunikasi matematika, ternyata terungkap bahwa tidak terdapat perbedaan kemampuan, baik pada aspek kemampuan berpikir kreatif maupun komunikasi matematis antara mahasiswa laki-laki dan mahasiswi perempuan di PMT UIN suska Riau.Berdasarkan telaah hasil penelitian di atas, terdapat keberagaman hasil penelitian mengenai aspek gender dalam pembelajaran matematika. Beberapa hasil menunjukkan adanya pengaruh faktor gender dalam pembelajaran matematika, namun pada sisi lain beberapa penelitian mengungkapkan bahwa gender tidak berpengaruh signifikan dalam pembelajaran matematika.

\section{PENUTUP}

Berdasarkan hasil penelitian dapat disimpulkan beberapa hal berikut, yaitu tidak terdapat hubungan yang signifikan antara self efficacy siswa laki-laki dengan hasil belajar matematika siswa laki-laki di kelas XI IPA 2 MAN 2 Batusangkar, tidak terdapat hubungan yang signifikan antara self efficacy siswi perempuan dengan hasil 
belajar matematika siswi perempuan di kelas XI IPA 2 MAN 2 Batusangkar, tidak terdapat perbedaan signifikan antara self efficacy siswa laki-laki dan perempuan di kelas XI IPA 2 MAN 2 Batusangkar, dan terdapat hubungan yang signifikanantara self efficacy siswa secara keseluruhan dengan hasil belajar matematika siswa secara keseluruhan di kelas XI IPA 2 MAN 2 Batusangkar.

Lokasi penelitian, latar belakang budaya, ekonomi, sosial dan sistem matrilineal yang ada di daerah Sumatera Barat kiranya turut berkontribusi terhadap self efficacy dan hasil belajar matematika di MAN 2 Batusangkar. Akses yang semakin terbuka dan setara bagi siswa laki-laki dan siswi perempuan memberikan pengaruh terhadap self efficacy dan hasil belajar matematika siswa. 


\section{DAFTAR PUSTAKA}

Abdurrahaman, Mulyono. 2003. Pendidikan Bagi Anak yang Berkesulitan Hasil Belajar. Jakarta: Rineka Cipta

Albert Bandura. 1997.Self Efficacy: The Exercise of Control.New York: Freeman. Tersedia : Http://www.des.emory.edu/mfp/giovaliante/html. (online) diakses 25 April 2016

. 1998. Self-Efifcacy Encyclopedia of Human Behavior. New York: Academic Press. Tersedia: http://WWW.des.emory.edu/mfp/giovaliante/html (online) diakses 25 April 2016

Bassey, S. M. et. al. 2008. Gender Differences and Mathematics Achievement of Rural Senior Secondary Students in Cross River State, Nigeria. Tersedia: https://www.researchgate.net/publication/254348567_Gender_Differences_a nd_Mathematics_Achievement_of_Rural_Senior_Secondary_Students_in_C ross_River_State_Nigeria. (online) diakses tanggal 27 September 2017

Debineva, Ferena 2016. Journal Review, Stereotipe Gender dan Kemampuan Spatial. Tersedia di https://sgrcui.wordpress.com/2016/03/07/journalreview-stereotip-gender-dan-kemampuan-spatiall. (online)diakses 20 September 2017

Ekawati, Aminah dan Wulandari, Shinta. 2011. Perbedaan jenis kelamin terhadap kemampuan siswa dalam mata Pelajaran matematika (studi kasus sekolah dasar). Jurnal Socioscientia Kopertis Wilayah XI Kalimantan. Februari 2011, volume 3 nomor 1

Frank Pajares dan Dale H. Schunk.Self Efficacy Theory The Development of Academic Self Efficacy. Tersedia: http://WWW.emory.edu/EDUCATION/mfp.eff.html(online) diakses 25 April 2016)

Frank Pajares dan Tim Urdan. 2006.Self Efficacy Belief of Adolescents. United States of America. Tersedia: http://www.emory.edu/FrankPajares/selfefficacyClearyAdo/html(online) diakses 25 April 2016

Hadaning, Galuh Budi. 2014. Hubungan Efikasi Diri dalam Perspektif Gender dengan Hasil Belajar Matematika Siswa kelas X SMA Al-Azhar Menganti Gresik. (Skripsi sarjana Universitas Islam Negeri Sunan Ampel Surabaya)

Ghufron, M. Nur. Rini Rinaswita, S. 2010. Teori-Teori Psikologi. Yogyakarta: ArRuzz Media 
Kumar, Rajesh dan Roshan Lal. 2006. The Role of Self Efficacy and Gender Difference among the Adolescents (Journal Vol. 32 Pp 249-254). (medind.nic.in, diakses pada 24 Desember 2015, 13.06 WIB).

Maccoby, E.E \&Jacklin,C.N. 1974. The Psychology of Sex Differences. Stanford: Stanford University

Maloney, E. A., Weachter, S. Risko, E. F., \& Fugelsang, J. A. 2012. Reducing the Sex Difference in Math Anxiety: the Role of Spatial Processing Ability.

MZ., Zubaidah, A. Perspektif Gender dalam Pembelajaran matematika. Jurnal Marwah. Vo. XII, No. 1. Juni Tahun 2013.

Nafi'an, Muhammad Ilman. 2011. Kemampuan Siswa dalam Menyelesaikan Soal Cerita ditinjau dari Gender di Sekolah Dasar. Prosiding Seminar Nasional Matematika dan Pendidikan Matematika dengan tema "Matematika dan Pendidikan Karakter dalam Pembelajaran" pada tanggal 3 Desember 2011 di Jurusan Pendidikan Matematika FMIPA UNY. ISBN: 978-979-16353-6-3

Ormrod, Jeanne Ellis. 2008. Psikologi Pendidikan Membantu Siswa Tumbuh dan Berkembang. Jakarta: PT Gelora Aksara Pratama

Purwanto. 2009. Evaluasi Hasil Belajar. Yogyakarta: Pustaka Pelajar

Pease, A., \& Pease, B. 1999. Why Men Dont Listen and Why Women Cant Read Road Maps: How Were Different and What to do abaout it. New York: Pease International.

Santrock, J. W. 2008. Psikologi Pendidikan. Edisi Dua. Jakarta: Kencana

Sudjana, Nana. 2004. Dasar-Dasar Proses Belajar Mengajar. Bandung: Sinar Baru Algesindo

Vogt, C. M., Hocevar, D., \& Hagedorn, L. S. 2007. A social cognitive construct validation: Determining women's and men's success in engineering programs. The Journal of Higher Education, 78, 337-364. doi:10.1353/jhe.2007.0019

Zubaidah. 2011. Meningkatkan Kemampuan Komunikasi Matematik Mahasiswa Melalui Pembelajaran Dalam Kelompok Kecil Tipe Team Assisted Individualization (TAI) Dengan Pendekatan Berbasis Masalah. Riset. Fakultas Tarbiyah dan Keguruan. Tidak dipublikasikan. 